\title{
Compartmentation and complexation of metals in hyperaccumulator plants
}

\section{Barbara Leitenmaier and Hendrik Küpper*}

Fachbereich Biologie, Universität Konstanz, Konstanz, Germany

\section{Edited by:}

Minglin Lang, Kansas State

University, USA

Reviewed by:

Denise Fernando, La Trobe University, Australia

Marjana Regvar, University of

Ljubljana, Slovenia

*Correspondence:

Hendrik Küpper, Fachbereich Biologie, Universität Konstanz, D-78457

Konstanz, Germany

e-mail: hendrik.kuepper@

uni-konstanz.de

\begin{abstract}
Hyperaccumulators are being intensely investigated. They are not only interesting in scientific context due to their "strange" behavior in terms of dealing with high concentrations of metals, but also because of their use in phytoremediation and phytomining, for which understanding the mechanisms of hyperaccumulation is crucial. Hyperaccumulators naturally use metal accumulation as a defense against herbivores and pathogens, and therefore deal with accumulated metals in very specific ways of complexation and compartmentation, different from non-hyperaccumulator plants and also non-hyperaccumulated metals. For example, in contrast to non-hyperaccumulators, in hyperaccumulators even the classical phytochelatin-inducing metal, cadmium, is predominantly not bound by such sulfur ligands, but only by weak oxygen ligands. This applies to all hyperaccumulated metals investigated so far, as well as hyperaccumulation of the metalloid arsenic. Stronger ligands, as they have been shown to complex metals in non-hyperaccumulators, are in hyperaccumulators used for transient binding during transport to the storage sites (e.g., nicotianamine) and possibly for export of $\mathrm{Cu}$ in $\mathrm{Cd} / \mathrm{Zn}$ hyperaccumulators [metallothioneins (MTs)]. This confirmed that enhanced active metal transport, and not metal complexation, is the key mechanism of hyperaccumulation. Hyperaccumulators tolerate the high amount of accumulated heavy metals by sequestering them into vacuoles, usually in large storage cells of the epidermis. This is mediated by strongly elevated expression of specific transport proteins in various tissues from metal uptake in the shoots up to the storage sites in the leaf epidermis. However, this mechanism seems to be very metal specific. Non-hyperaccumulated metals in hyperaccumulators seem to be dealt with like in non-hyperaccumulator plants, i.e., detoxified by binding to strong ligands such as MTs.
\end{abstract}

Keywords: hyperaccumulator/hypertolerance, excluder, metal sequestration, metal transport, metal storage cells, organic acids, phytochelatin

\section{INTRODUCTION}

Many heavy metals such as copper, manganese, nickel, and zinc are well-known as essential trace elements for all living organisms, mainly as active centers of enzymes. And surprisingly even cadmium, which never has been thought to be essential for any organism, has been found to be a micronutrient for the marine alga Thalassiosira weissflogii, where it builds up the active center of a carbonic anhydrase (Lane and Morel, 2000). For land plants no essential role for cadmium is known to date, although it has been shown to be beneficial for Cd hyperaccumulators as a defense against pathogens and herbivores (Jiang et al., 2005), and in the southern French populations of the Cd/Zn hyperaccumulator Noccaea (=Thlaspi) caerulescens (Brassicaceae) even a growth reduction in absence of $\mathrm{Cd}$ was observed without influence of pathogens or herbivores (Liu et al., 2008).

Abbreviations: CAX, cation exchanger; $\mathrm{CDF}$, cation diffusion facilitator; CPx-type, ATPases adenosine-tris-phosphatases with the specific intramembranous amino acid motif cysteine-proline-cysteine or cysteine-proline-histidine; $\mathrm{E}_{\mathrm{A}}$, energy of activation in kJ.mol-1; EDTA, ethylenediaminetetraacetic acid; EXAFS, extended Xray absorption fine structure; HMA, heavy metal ATPase; mRNA, messenger RNA (Ribonucleic acid); Nramps, natural resistance-associated macrophage proteins; XAS, X-ray absorption spectroscopy
In many places worldwide, heavy metals can occur in very high concentrations that are detrimental or even lethal to most plant species. These high concentration are sometimes due to natural factors, leading to natural metallophyte communities, for example in special regions in Africa like the "copper belt" in the Republic of Congo where copper ore naturally comes to the surface (e.g., Duvigneaud, 1958; Malaisse et al., 1999). In many other cases, however, they are caused by human activities (e.g., Romic and Romic, 2003). As prominent examples, they are known to be results of mining (and smelters), where cadmium is often found together with zinc (Buchauer, 1973; Van Geen et al., 1997; Liu et al., 2005), and also high amounts of copper in the soil are found in mining areas (Ke et al., 2007). The same applies for manganese in parts of Southern China (Li et al., 2007). But also application of sewage sludge (McBride et al., 1997) and dust from car tires ( $\mathrm{Cd}$ is a softener for rubber) along roadsides contributed to $\mathrm{Cd}$ pollution (Fergusson et al., 1980). Metal pollution is also found in rivers all over Europe (Audry et al., 2004), especially in regions rich in vineyards, as copper is still used as a classical reagent against fungal attacks toward vine plants (Küpper et al., 1996; Ribolzi et al., 2002; He et al., 2009; Mackie et al., 2012; Ruyters et al., 2013). 
Based on their ability to cope with metals in the medium they grow on/in, plants can be divided into three types:

(1) Indicator plants are usually sensitive to heavy metals. They can be used as an indicator for metal in the soil because the internal heavy metal concentration is a linear function of the bioavailable heavy metal concentration in the soil (or water for aqueous plants/nutrient solution for hydroponics).

(2) Excluders are a type of plants being able to tolerate heavy metals in the soil up to a threshold concentration by preventing the accumulation of metal in the cells. This exclusion is achieved either by blocking the uptake in the roots (see, e.g., Lux et al., 2011 for a detailed review) or by active (energy dependent) efflux pumps (Baker, 1981; van Hoof et al., 2001). Most metal (hyper)tolerant plants belong to this group (Baker, 1981).

(3) Most important for this topic are plants that can not only tolerate high concentrations of specific elements, but take them up actively and accumulate them to several percent of the dry mass of their above-ground parts. Originally described by Sachs (1865), since 1977 those plants are called hyperaccumulators (Brooks et al., 1977). Many studies on many metals, plant and pathogen species have shown that the hyperaccumulation phenotype naturally serves as a defense against pathogens and herbivores (Boyd and Martens, 1994; Martens and Boyd, 1994; Boyd et al., 2002; Hanson et al., 2003; Jhee etal., 2005 and many further studies since then, discussed in detail, e.g., in the reviews by Küpper and Kroneck, 2005, 2007). In this context, it should be mentioned that hyperaccumulation and hypertolerance are, according to studies on several hyperaccumulator species, genetically independent characters (Macnair et al., 1999; Bert et al., 2003). However, this "independence" is limited because a hyperaccumulator would poison itself if the accumulated metal would not be tolerated via specific mechanisms. More recent works also genetically question this independence, showing partially overlapping quantitative trait loci for accumulation and tolerance (Frérot et al., 2010; Willems et al., 2010). Hyperaccumulators have been found for many heavy elements and within many groups of plants and algae, including at least the following: $\mathrm{Al}, \mathrm{As}, \mathrm{Cd}, \mathrm{Cu}, \mathrm{I}, \mathrm{Mn}, \mathrm{Ni}, \mathrm{Se}, \mathrm{Zn}$. More hyperaccumulators and hyperaccumulated elements are likely to be found as screening for this phenotype is ongoing and there is still a lot of debate about the definition of hyperaccumulation thresholds. However, nickel hyperaccumulators are by far the most numerous group (several hundred species are known) and biotechnology-oriented research focused on those metals where phytomining and/or phytoremediation are attractives uses, i.e., As, $\mathrm{Cd}, \mathrm{Cu}, \mathrm{Ni}$, and $\mathrm{Zn}$ (see recent reviews, e.g., by Whiting et al., 2004; Chaney et al., 2005, 2007; Küpper and Kroneck, 2005, 2007). In this review, also we put most emphasis on the latter group of metals, but mention other hyperaccumulated elements as well when their complexation and/or compartmentation is different from this "core group" of hyperaccumulated elements. Furthermore, it should be noted that the mechanisms leading to accumulation of metals in hyperaccumulators are specific for one element or at maximum a few elements (see Figure $\mathbf{1}$ for a short comparison between accumulated and non-accumulated metals). For example, while $N$. caerulescens accumulates up to several percent of its dry mass of both zinc and (only in case of the southern French populations) $>2 \%$ of cadmium as well, its accumulation of copper is not elevated compared to non-accumulator species (Mijovilovich et al., 2009), the same applies to As, and it accumulates even less Mn than excluder species (Martínez-Alcalá et al., 2013). Thus it is important to mention that the hyperaccumulation ability always depends strongly on the population and the metal - it is not possible to say that a specific species as such is a hyperaccumulator.

Depending on the type of plant, a number of strategies to resist the toxicity of heavy metals are known (for a quick summary, see Figure 1). In general, metal tolerance mechanisms include sequestration in specific cell types and intracellular compartments where metals can do the least harm, changing the speciation to less toxic forms by redox mechanisms, precipitation, or binding of metals to ligands, as well as export of metals out of the cells and plants. Since in principle this has been reviewed earlier (Prasad and Hagemeyer, 1999; Cobbett and Goldsbrough, 2002; Küpper and Kroneck, 2005; Verbruggen et al., 2009; Krämer, 2010 for general reviews; for cadmium accumulation Küpper and Leitenmaier, 2013), the current review will focus on recent new developments in this field that are relevant for a range of different metals.

As the most important mechanisms of metal tolerance in hyperaccumulating plants, compartmentation in specific storage cells as well as various ligands for detoxification and storage of metals will be discussed in the following. Furthermore, differences in metal compartmentation/complexation between hyperaccumulation and non-hyperaccumulating metal metabolism will be highlighted (for an overview, see also Figure 1).

\section{COMPLEXATION}

In non-hypertolerant indicator plants, binding of metals by strong ligands is the main detoxification strategy. The best known type of ligands for this purpose are thiols, including glutathione, phytochelatins (PCs), and metallothioneins (MTs). In addition, some non-thiol ligands are involved, and the non-thiol ligands have a decisive role in hyperaccumulators. Already in 1996 histidine had been shown to be a main ligand of $\mathrm{Ni}$ in the Ni hyperaccumulator Alyssum lesbiacum (Krämer et al., 1996). In more recent times, the non-proteogenic amino acid nicotianamine has been shown to be involved in metal accumulation. Nicotianamine, glutathione, and MTs also have other functions for non-hyperaccumulated metals, such as transient binding during transport to the storage sites, storage and metal re-mobilization at times when metals are needed for active centers of enzymes, etc. PCs, in contrast, seem to be synthesized specifically for metal(loid) detoxification, particularly in the case of As and Cd (reviewed by Cobbett and Goldsbrough, 2002).

\section{CYSTEINE}

Cysteine is well-known to be the most important metal-binding amino acid residue in proteins. Furthermore, as discussed below, it is a building block of PCs, the main As and Cd detoxifying compounds in non-hyperaccumulator plants. As a free amino acid, however, it has not been identified to be involved in binding metals for detoxification.

\section{HISTIDINE}

Histidine is, besides the thiol ligand cysteine, the second most important amino acid residue forming metal-binding sites in metalloproteins, and both residues often are combined in the same site. 


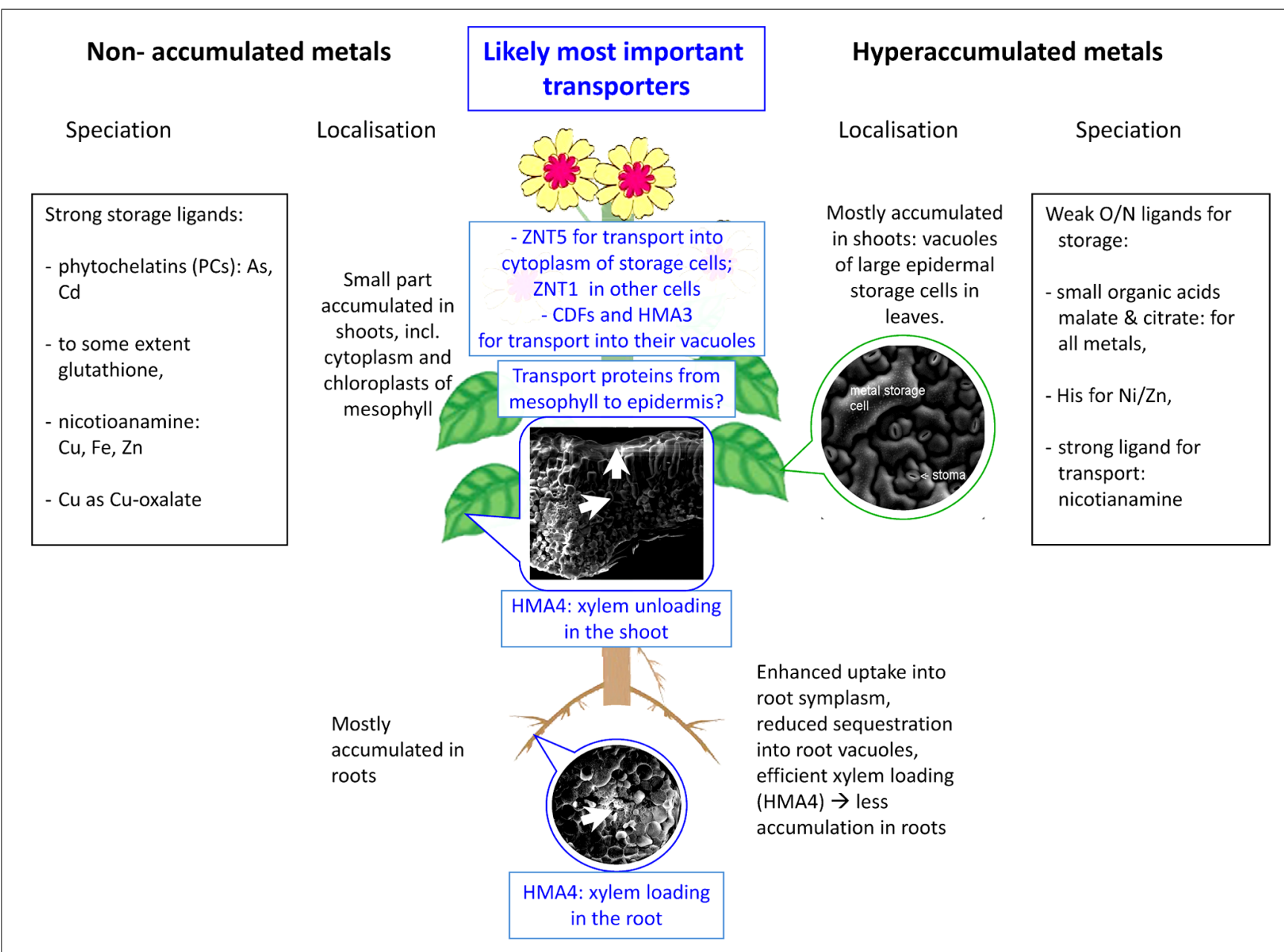

FIGURE 1 | Scheme of selected important aspects of metal sequestration and speciation in hyperaccumulated compared to non-hyperaccumulated metals - the latter includes non-accumulated metals in hyperaccumulators (e. g., copper in the $\mathrm{Cd} / \mathrm{Zn}$ hyperaccumulator Noccaea caerulescens. The SEM micrographs show typical tissue morphology in hyperaccumulators and were taken during studies of HK. Epidermis with stomata: Noccaea goesingense; leaf cross-section: Alyssum bertolonii; root cross-section: Arabidopsis halleri.
Less known, however, is the role of the free amino acid histidine as a metal ligand. It was first shown to bind a major proportion of $\mathrm{Ni}$ in the $\mathrm{Ni}$ hyperaccumulator Alyssum lesbiacum (Krämer et al., 1996), but later it was found to be involved in binding zinc in hyperaccumulators as well (Salt et al., 1999; Küpper et al., 2004). In Alyssum lesbiacum, histidine was suggested to enhance loading of $\mathrm{Ni}$ into the xylem by a co-release of $\mathrm{Ni}$ and His into the xylem (Kerkeb and Krämer, 2003). In this context it is important to say that free histidine as a simple monodentate ligand is not binding metals very strongly, in contrast to the multi-histidine residue metal-binding sites in proteins. In this way, free histidine is important as a ligand most likely only in compartments where stronger ligands are scarce, e.g., the vacuole, xylem, or transport vesicles inside the cytoplasm, although low $\mathrm{pH}$ might limit complexation of metals by histidine in the vacuole and xylem. In the phloem, also stronger metal ligands (MTs, see below) were found, but histidine might bind metals there if the higher affinity sites are occupied. In the cytoplasm itself, in contrast, histidine most likely is an important ligand only as an amino acid residue of metal-binding proteins unless these high-affinity sites are already saturated with an excess of metal and all other detoxification ligands would be occupied (i.e., conditions of severe toxicity). Because of this, an alternative explanation seems more likely for the results of Richau et al. (2009). These authors demonstrated that addition of histidine to roots of $N$. caerulescens enhances loading of the xylem with $\mathrm{Ni}$, but can block loading of Ni into isolated vacuoles. From the latter observation they concluded that $\mathrm{Ni}$ would bind to free His in the cytoplasm. In view of the facts discussed above, it seems more likely that His did not bind Ni directly in the cytoplasm, but in transport vesicles. Metal-rich vesicles have been observed in the cytoplasm of cells of hyperaccumulators (Neumann and De Figuero, 2002; Leitenmaier and Küpper, 2011), but so far it was not possible to analyze metal speciation in such small compartments.

\section{NICOTIANAMINE}

As a polydentate ligand with three carboxyl groups and three nitrogens, this molecule is a rather strong ligand with $\mathrm{pKs}$ of 12.1 for $\mathrm{Fe}^{2+}, 14.7$ for $\mathrm{Zn}^{2+}, 16.1$ for $\mathrm{Ni}^{2+}$, and 18.6 for $\mathrm{Cu}^{2+}$ (Beneš 
et al., 1983), structurally very similar to the iron phytosiderophore mugeinic acid. However, for $\mathrm{Zn}$ and $\mathrm{Fe}$ these binding constants are still lower than those of typical metal-centers in metalloproteins. Nicotianamine provides six alternating carboxylate and amine functions; their relative positions favor the formation of sixcoordinate metal complexes (Callahan et al., 2006). Its main role is still a matter of debate, it has been associated originally with iron metabolism (it binds both iron(II) and iron(III); Scholz et al., 1992; von Wiren et al., 1999). Soon after, it was shown to be important for copper metabolism (Pich et al., 1994; Pich and Scholz, 1996; Liao et al., 2000; Irtelli et al., 2009), and it was found to bind a significant proportion of total copper at physiologically relevant toxic concentrations in $N$. caerulescens (that does not hyperaccumulate copper; Mijovilovich et al., 2009). Also binding of zinc to nicotianamine was shown in vivo (Trampczynska et al., 2010). The latter, combined with elevated expression of NA synthase in the $\mathrm{Cd} / \mathrm{Zn}$ model hyperaccumulators Arabidopsis halleri and $\mathrm{N}$. caerulescens (Becher et al., 2004; Weber et al., 2004; van de Mortel et al., 2006, 2008) led to the question whether it may play a role in long-distance zinc transport in hyperaccumulators and therefore be an essential part of the hyperaccumulator phenotype. This hypothesis was farther supported by the finding that $\mathrm{Ni}$ in the xylem sap of $N$. caerulescens is partially present as stable Ni-NA complex (Mari et al., 2006). Recently, knocking down nicotianamine synthase by RNAi technology in Arabidopsis halleri has revealed that in such plants $\mathrm{Zn}$ and $\mathrm{Cd}$ accumulation is severely diminished, indicating that NA is indeed important for hyperaccumulation of these metals (Deinlein et al., 2012).

Taking the information above together, when present in low concentrations nicotianamine likely is important as a ligand mostly in compartments with low abundance of stronger ligands (e.g., the vacuole, xylem, and phloem). At the very high nicotianamine levels in hyperaccumulators, however, it might also take part in binding of these metals in the cytoplasm, although direct evidence for that [e.g., extended X-ray absorption fine structure (EXAFS) spectroscopy with subcellular resolution on intact frozen-hydrated tissues] is still missing because it is currently not yet possible due to technical reasons.

\section{OTHER NON-THIOL LIGANDS/DETOXIFYING ANIONS}

While histidine and nicotianamine are becoming more known as relevant metal ligands in plants, also other non-thiol ligands have been shown to make a major contribution in particular cases, and it is possible that their actual importance is grossly underestimated. One such example are anthocyanins, which have been shown to be associated with molybdenum accumulation (Hale et al., 2001). Another such case is oxalate, which was first shown to bind copper in copper $(\mathrm{Cu})$-tolerant lichens and fungi (Chisholm et al., 1987; Fomina et al., 2005; Purvis et al., 2008) and also has been reported [by X-ray absorption spectroscopy (XAS) studies] to be the major ligand for manganese in Phytolacca acinosa Roxb. and Phytolacca americana (Phytolaccaceae; Dou et al., 2009; Xu et al., 2009). Furthermore, oxalate turned out to contribute a major part to copper binding in the copper sensitive $\mathrm{Cd} / \mathrm{Zn}$ hyperaccumulator $N$. caerulescens, particularly in the more $\mathrm{Cu}$-tolerant individuals of the population (Mijovilovich et al., 2009). While binding to oxalate will really detoxify copper and manganese, since copper and manganese oxalates are hardly soluble and a rather stable complex, binding to smaller organic acids like malic or citric acid will not significantly diminish bioavailability of toxic metals. For this reason, at first glance it is surprising that in various hyperaccumulator plants most of the hyperaccumulated metal(loid)s are associated with such organic acids (As: Wang et al., 2002, Cd: Küpper et al., 2004; Cu: Küpper et al., 2009; Mn, in various species outside the family of Phytolaccaceae: Fernando et al., 2010; Ni: Sagner et al., 1998; Zn: Salt et al., 1999). It is logical, however, in context with the compartmentation of metals in vacuoles of such plants, see next chapter of this review for details. In these compartments, in all plants high levels of malate and citrate are stored, so that storage of the metal(loid)s in the same compartment will inevitably lead to a weak association of both.

Organic acid ligands may also play a role in enhanced uptake of metals into the roots of hyperaccumulators. A recent study ( $\mathrm{Li}$ et al., 2012) has shown that dissolved organic matter (DOM) in the rhizosphere of a hyperaccumulator ecotype of Sedum alfredii contained more organic acids and mobilized zinc better than DOM from a non-accumulator ecotype of $S$. alfredii.

\section{METALLOTHIONEINS}

Metallothioneins are the best known metal detoxifying ligands, because they have been known from animal physiology for a very long time (reviewed by Cobbett and Goldsbrough, 2002). Soon, they were found in plants as well, although in less variants than in animals (for a review, see Freisinger, 2011). Their role in plants, however, seems to be significantly different from animals. In plants (non-hyperaccumulator plants as well as hyperaccumulators), their main role seems to be metal homeostasis under normal, non-toxic physiological conditions. For example, upregulation of MTs has been shown to occur during senescence of plant tissues for re-mobilization of copper (original research: BuchananWollaston, 1994; Guo etal., 2003; Heise et al., 2007), and MT expression has been shown in the phloem (Vilaine et al., 2003; Barnes et al., 2004). Furthermore, Zn-MTs seem to be involved in physiological $\mathrm{Zn}$ deposition in developing seeds. Here, the best studied case is the MT Ec1 from wheat (Kawashima et al., 1992; Peroza and Freisinger, 2007; Loebus et al., 2011). In terms of detoxification, they seem not to be very important for Cd, but do play a role for $\mathrm{Cu}$ (reviewed by Cobbett and Goldsbrough, 2002). The study of Garcia-Hernandez etal. (1998) suggested that MT1 is important for scavenging copper mainly in leaf veins; as copperinduced MT1 expression was observed mainly in leaf veins and to a lesser extent in mesophyll cells, while hardly any induction of MT1 in response to copper stress was observed in roots.

In hyperaccumulator plants, MTs are not important for storage of the hyperaccumulated metals, as these are generally not bound by thiol ligands (see other Non-Thiol Ligands/Detoxifying Anions). Nevertheless, they were found to be overexpressed in the $\mathrm{Cd} / \mathrm{Zn}$ hyperaccumulator $N$. caerulescens compared to related non-accumulators (Papoyan and Kochian, 2004). In our opinion, the most likely reason for this seemingly contradictory facts is detoxification of copper by MTs in hyperaccumulators of other metals (e.g., Cd, $\mathrm{Zn}, \mathrm{Ni}$ ) that are sensitive toward copper (Walker and Bernal, 2004; Mijovilovich et al., 2009). This is likely important for $\mathrm{Cd} / \mathrm{Zn}$ hyperaccumulation, because due to 
the Irving-Williams series of binding strength of metals to ligands, also $\mathrm{Cu}$ will inevitably be transported by the in $\mathrm{Cd} / \mathrm{Zn}$ hyperaccumulators highly overexpressed $\mathrm{Cd} / \mathrm{Zn}$ transport proteins (Pence et al., 2000; Frausto da Silva and Williams, 2001). This copper transport was experimentally shown for the Cd/ZnATPase HMA4 (Leitenmaier et al., 2011). This unintended but unavoidable transport of $\mathrm{Cu}$ would lead to copper accumulation and copper toxicity in $\mathrm{Cd} / \mathrm{Zn}$ hyperaccumulators if those species would not have mechanisms to eliminate excess copper. Thus we hypothesize that $\mathrm{Cu}$ binding by MTs is a step in this Cu detoxification and finally elimination. MTs were shown to bind $\mathrm{Cu}$ in these plants under relevant conditions in the $\mathrm{Cd} / \mathrm{Zn}$ hyperaccumulator N. caerulescens (Mijovilovich et al., 2009), and for chemical reasons likely in other $\mathrm{Cd} / \mathrm{Zn}$ hyperaccumulators. In that study, in the EXAFS analyses clearly a strong contribution of sulfur ligands to binding of copper was found in most of the samples. Further, copper(I) MTs are known to form very rigid copper-sulfur clusters (Calderone et al., 2005) that stabilize copper(I) in aqueous solution (Byrd et al., 1988), yielding characteristic multiple scattering signals in EXAFS spectra as they were detected in the study of Mijovilovich et al. (2009). The role of MTs in copper detoxification in hyperaccumulators is further supported by studies on MT3 in N. caerulescens, which showed enhanced copper binding capabilities (Roosens et al., 2004; Fernandez et al., 2012). The pathway of copper efflux in $\mathrm{Cd} / \mathrm{Zn}$ hyperaccumulators after the binding to MTs, which must exist as they do not accumulate copper (Mijovilovich et al., 2009), is not yet known.

\section{PHYTOCHELATINS}

Phytochelatins were discovered as heavy metal detoxifying ligands almost 30 years ago (Grill et al., 1985, 1989). In contrast to MTs, PCs seem not to be involved in normal metal metabolism under non-toxic conditions; neither a function in delivery of metals to metalloproteins nor in the storage of essential metals has been convincingly shown. Biochemically inhibiting (Schat et al., 2002) or genetically inducing PC synthase deficiency (cad1 mutant: Howden etal., 1995) makes non-hypertolerant plants hypersensitive to metal(loid) toxicity. Furthermore, many studies in non-hypertolerant plants have shown the induction of PC synthase by very low concentrations of metal(loid)s, in particular Cd and As (e.g., Hartley-Whitaker et al., 2001, and very recently Andresen et al., 2013), as they frequently occur in the environment. Thus, in our opinion on the basis of the evidence available, it is not enigmatic why PC synthase is present in all plants. Additionally, it is important to note that lack of PC synthase expression (the cad1 mutant) specifically leads to Cd hypersensitivity, without disturbance of growth at really low Cd (Howden et al., 1995). At "0" $\mathrm{Cd}$ in wildtype, these and other authors found about $3 \%$ of the PC level present at $30 \mu \mathrm{M} \mathrm{Cd}$, which might be interpreted as an indication that PCs are needed even without Cd stress. However, all chemicals, labware, and water contain trace amounts of $\mathrm{Cd}$, easily leading to nanomolar Cd concentrations in nutrient solution that were recently found to induce an increased PC synthesis (Andresen et al., 2013). In the latter study, PC levels dropped to almost undetectable levels if better than ACS grade chemicals (e.g., Suprapur/TraceSelect), ultraclean water and acid washed labware were used to push minimum Cd levels below $1 \mathrm{nM}$. Thus, the majority of data available so far strongly suggests that PC synthase is required only for metal(loid) detoxification. It has been reported that PC synthase contributes to degradation of glutathione conjugates (Blum et al., 2007; Wünschmann et al., 2010; Rigouin et al., 2013), but since PC synthase deficient mutants have no diminished growth when growing without As/Cd toxicity stress, the essentiality of this PC function remains to be shown. For metal(loid)s other than As and Cd the affinity to PCs and/or the induction of PC synthesis is too low to be relevant under natural conditions (e.g., Maitani et al., 1996; Satofuka et al., 2001; Schat et al., 2002). There is also a report that PCs would be involved in $\mathrm{Zn}$ detoxification (Tennstedt et al., 2009). But in this study, Zn hypersensitivity upon PC synthase knockout was observed only in yeast cells where the main $\mathrm{Zn}$ detoxification mechanism ( $\mathrm{Zn}$ homeostasis factor, $\mathrm{Zhf}$, Clemens et al., 2002) had been knocked out as well, and in Arabidopsis thaliana plants grown with $50 \mu \mathrm{M} \mathrm{Zn}$, i.e., concentrations above the range this species may encounter in nature.

Interestingly, PCs are not required for metal tolerance in hypertolerant plants. In such plants (regardless of whether they are hyperaccumulators or not), the inhibition of PC synthase did not change the tolerance toward metals significantly (Schat etal., 2002). Comparing different ecotypes of $N$. caerulescens, these authors furthermore showed that in the non-Cd-hyperaccumulating, Cd-sensitive populations blockage of PC synthesis made the already Cd-sensitive populations (and only those) even more sensitive to Cd toxicity, i.e., they behaved like all non-hypertolerant/non-accumulator other species would do. Additionally, metal hyperaccumulator plants were found to have lower PC levels than related non-accumulator plants (Ebbs et al., 2002). Furthermore, in contrast to MTs (see above), PCs do not seem to be involved in binding of the non-hyperaccumulated but toxic copper in the $\mathrm{Cd} / \mathrm{Zn}$ hyperaccumulator $N$. caerulescens (Mijovilovich et al., 2009). This could again be shown by EXAFS spectroscopy. Copper PCs have a completely different EXAFS spectrum than $\mathrm{Cu}-\mathrm{MTs}$, with only one strong $\mathrm{Cu}-\mathrm{Cu}$ interaction peak at $2.56 \AA$ and a weak contribution at $4.04 \AA$ (Polette et al., 2000 ), but no contribution at distances where peaks in the Fourier transforms were observed (Mijovilovich et al., 2009).

\section{GLUTATHIONE}

Glutathione is the main building block which PC synthase uses for making PCs. Besides this indirect involvement in metal detoxification, there are also some indications that glutathione itself acts as a low-affinity (monodentate) ligand for Cd. Pietrini et al. (2003) have found, using 50-100 $\mu \mathrm{M}$ cadmium to induce toxicity in Phragmites australis, a 30-fold increase in the concentration of reduced glutathione in leaves. In contrast, cadmium and copper at more realistic concentrations $(0.03-3 \mu \mathrm{M}$ total dissolved Cd) that already caused a strong induction of PCs in phytoplankton did not lead to upregulation of glutathione synthesis under metal stress conditions (Ahner et al., 2002). In hyperaccumulators, no upregulation of glutathione levels in response to metal uptake has been reported so far, and (as mentioned before) thiol ligands are generally not much involved in metal storage in hyperaccumulators (As: Wang et al., 2002; Cd: Küpper et al., 2004; Cu: Küpper et al., 2009; Ni: Sagner et al., 1998; Zn: Salt et al., 1999). However, a constitutive high level of glutathione biosynthesis may contribute 
to protection against reactive oxygen species (not metal complexation) in Ni hyperaccumulators belonging to the Noccaea (formerly Thlaspi) genus (Freeman et al., 2004).

\section{OTHER LIGANDS}

As an exception to the rule of storage of hyperaccumulated elements predominantly in association with organic acids (see above), in selenium hyperaccumulators Se was found to be mainly stored as methylselenocysteine and g-glutamyl-methylselenocysteine (Freeman et al., 2006).

\section{COMPARTMENTATION}

\section{ENHANCED TRANSLOCATION OF METALS FROM ROOTS TO THE SHOOT}

While metal uptake through the root is the first important step in hyperaccumulation in land plants, most of the metal is stored in the shoots. Storage in the above-ground tissues is part of the definition of hyperaccumulators, and since the original discovery almost 150 years ago (Sachs, 1865) many studies throughout many decades have shown this phenotype (reviews, e.g., by Baker, 1981; Brooks, 1998; Küpper and Kroneck, 2005). As a particularly detailed recent long-term study dealing with cadmium uptake, Lovy et al. (2013) show that in the Cd/Zn hyperaccumulator $N$. caerulescens, exposed to constant $\mathrm{Cd}$ concentrations throughout the complete growth cycle, $86 \%$ of the Cd taken up was allocated to the shoots.

As a prerequisite for efficient transport from the roots to the above-ground parts of the plant, in numerous studies an enhanced uptake of metals into the root symplasm was found. In the $\mathrm{Cd} / \mathrm{Zn}$ hyperaccumulator $N$. caerulescens compared to the related non-accumulator, $N$. arvense (Lasat et al., 1996, 1998), the hyperaccumulator showed a much higher translocation efficiency and further, a reduced sequestration into the root vacuoles was associated with the higher root to shoot translocation efficiency of N. caerulescens (Shen et al., 1997; Lasat et al., 1998; Zhao et al., 2006). Also in the S. alfredii (Crassulaceae), found on highly Cd/Zn contaminated soils in the Zhejiang Province of China, Cd/Znhyperaccumulating and non-accumulating populations have been compared. This showed a very efficient xylem loading of zinc, leading to sequestration to the shoot in the hyperaccumulating populations ( $\mathrm{Lu}$ et al., 2013), while in the non-accumulating populations more of the metal was found in the roots.

The early finding that root uptake and root to shoot translocation are strongly elevated in hyperaccumulators compared to non-accumulators (see above) got a genetic basis in recent years, as it was found that the heavy metal ATPase HMA4 is strongly overexpressed in roots of the Cd/Zn hyperaccumulator plants Arabidopsis halleri and N. caerulescens (Bernard et al., 2004; Papoyan and Kochian, 2004; Weber et al., 2004), and that this is linked to HMA4 gene multiplication (Talke etal., 2006; Hanikenne et al., 2008; O'Lochlainn et al., 2011). Overexpression experiments strongly suggest that HMA4 functions in loading $\mathrm{Cd}$ and $\mathrm{Zn}$ into the xylem (Verret et al., 2004; Hanikenne et al., 2008). This conclusion is further supported by the finding that expressing it in yeast causes efflux (Papoyan and Kochian, 2004), because loading of the dead xylem tubes always means efflux from the helper cells surrounding them, where HMA4 is most highly expressed (Hanikenne et al., 2008). Also in rice (Oryza sativa) HMAs play an important role in the transport of $\mathrm{Cd}$ and $\mathrm{Zn}$ (for a review, see Takahashi et al., 2012), making these proteins an interesting topic to study, as in contrast to hyperaccumulators, rice is one of the most important cereals worldwide. An exception from the rule of active enhanced root to shoot transport in hyperaccumulators seems to be $\mathrm{Al}$, which is most likely transported apoplastically (Matsumoto et al., 1976).

\section{TRANSPORT TOWARD THE FINAL STORAGE CELLS VIA OVEREXPRESSED TRANSPORT PROTEINS}

Xylem loading and xylem transport and thus distribution of metals away from the roots and toward the final storage sites are key steps in metal hyperaccumulation, as it was commented by White et al. (2002).

It has been found that metal hyperaccumulation is mediated, at least in part, by an up to 200 times higher expression of various metal transporter genes in hyperaccumulators compared to related non-accumulator plants (Pence et al., 2000; Assunção et al., 2001; Becher et al., 2004; Papoyan and Kochian, 2004; Hanikenne et al., 2008, reviewed by Verbruggen et al., 2009). As the name suggests, hyperaccumulators are characterized by strong accumulation, compared to the substrate, of a certain element. This is usually expressed as the bioaccumulation factor, which is commonly defined as the ratio of the concentration of an element inside the organism compared to the metal concentration in the substrate. To achieve a bioaccumulation coefficient far greater than one [characterizing hyperaccumulators as revealed already by their first discovery almost 150 years ago (Sachs, 1865)], the metals have to be pumped into their storage sites against the concentration gradient. Altogether, most likely many steps of the metal transport from root uptake until passage over the vacuolar membrane of the storage cells are against the concentration gradient. Therefore, all these transport steps require an active, i.e., energy consuming transport system (Salt and Wagner, 1993). Furthermore, specificity of the transport is tightly controlled. This is obvious in $N$. caerulescens, which hyperaccumulates $\mathrm{Cd}$ and $\mathrm{Zn}$ but does not accumulate copper when it is supplied to the nutrient solution at the same concentration (Mijovilovich et al., 2009). Furthermore, this species is, apart from some more resistant individuals, highly sensitive toward copper (Mijovilovich et al., 2009). This copper sensitivity is a severe problem for phytoremediation of sites that are contaminated with a combination of several metals (Walker and Bernal, 2004)

As just discussed, during the last decade numerous studies have been undertaken successfully to identify genes that are involved in metal transport in hyperaccumulators. Attempts to isolate and characterize the corresponding proteins where less successful, due to the often cysteine-rich sequences of metal-binding and metal transport proteins. Because of this high cysteine content making them prone to oxidation, these proteins tend to be extremely unstable once taken out of their natural membrane environment, rendering them difficult to handle during characterization studies (Parameswaran et al., 2007; Leitenmaier et al., 2011). Nevertheless, also on the protein level there are now a few studies available, yielding insight into function and properties of such proteins and showing how also other metal transport proteins, which are highly expressed in hyperaccumulators, should be characterized in the 
future. Investigations of the biochemical and biophysical properties of the $N$. caerulescens version of HMA4, NcHMA4, have shown that the ATPase function of this transporter is activated most strongly by $\mathrm{Cd}$ and $\mathrm{Zn}$. Gels and western blots (using an antibody specific for NcHMA4) of crude root extract and of the purified protein revealed a size of NcHMA4 of about $50-60 \mathrm{kDa}$, while the mRNA for the NcHMA4 gene predicts a single protein with a size of $128 \mathrm{kDa}$. This indicates the occurrence of posttranslational processing (Parameswaran et al., 2007). Whether this shortened but functional protein is the product of the C-terminally truncated copies of the gene (Craciun et al., 2012) still remains unknown. In recent work by Leitenmaier et al. (2011), NcHMA4 showed activity of NcHMA4 with $\mathrm{Cu}^{2+}, \mathrm{Zn}^{2+}$, and $\mathrm{Cd}^{2+}$ under various concentrations $(0.03-10 \mu \mathrm{M}$ tested), and all three metal ions activated the ATPase at a concentration of $0.3 \mu \mathrm{M}$, while there were clear differences in activation energy $\left(\mathrm{E}_{\mathrm{A}}\right)$ observed, depending on the metal applied. According to EXAFS, NcHMA4 appeared to bind Cd mainly by thiolate sulfur from cysteine, and not by imidazole nitrogen from histidine. These properties correspond well with what is known from a study of a human copper ATPase, ATP7A (Hung et al., 2007). Maximal activation of NcHMA4 and HsATP7b occurred at about the same metal concentration, and also the measured turnover rates were similar (Leitenmaier et al., 2011 vs. Hung et al., 2007). Therefore, also the other properties, investigated in only one of these two existing biochemical studies of CPx-type ATPase holoproteins, should be at least somewhat similar in the other. In this way, research on plant metal transport proteins has also medical relevance as mutations of the human copper ATPases cause well-known deadly diseases (Menkes and Wilson disease).

The expression of HMA4 not only in the roots but also in shoots clearly shows that it must have more functions than xylem loading. Expression is similarly high also in shoots, again with a maximum in the vascular bundle, which could mean that this protein is involved in xylem unloading as well (Craciun et al., 2012). Such a role dual role both in loading and unloading of the xylem by the same protein could be achieved simply by insertion of the protein in either the xylem-facing side of these cells ( $\rightarrow$ loading) or the opposite side ( $\rightarrow$ unloading). How the passage through the mesophyll to the epidermal storage cells is accomplished is still an open and important question, as shown also by the fact that HMA4 overexpression in a non-accumulator causes this plant to poison itself due to lack of mechanisms detoxifying the $\mathrm{Cd}$ and $\mathrm{Zn}$ arriving in the shoots (Hanikenne et al., 2008). Uptake over the cytoplasmic membrane of the epidermal storage cells is not wellcharacterized either, but a recent study on the cellular distribution and regulation of gene expression levels (Küpper and Kochian, 2010) indicates genes that may be candidates for causing this difference in metal accumulation between epidermal cells: NcZNT5 was highly expressed in epidermal storage cells, much higher than in other cell types. The ZIP-family of transporters, to which ZNT5 belongs, is generally localized in the plasma membrane (review by Guerinot, 2000).

\section{FINAL STORAGE SITE: VACUOLES OF LARGE EPIDERMAL CELLS}

Hyperaccumulators have to store the enormous amounts of taken up metal in a way that it does not harm important enzymes and especially not photosynthesis, therefore it is crucial to keep the metal concentration in the cytoplasm of mesophyll cells as low as possible. It makes sense for hyperaccumulating plants to store metal in the vacuoles because in this organelle only enzymes like phosphatases, lipases, and proteinases (Wink, 1993; Carter et al., 2004) are present, which have not been found to be a target of heavy metal toxicity. Additionally it has been shown that high amounts of metals are stored specifically in the vacuoles of large epidermal cells (Küpper et al., 1999, 2001; Frey et al., 2000), where no chloroplasts are located and therefore also during transport through the cytoplasm harboring the chloroplasts, photosynthesis cannot be inhibited. Preferential storage of hyperaccumulated metals in the epidermis has been shown for the majority of hyperaccumulator species and for elements as chemically diverse as Al, As, Cd, Ni, Se, and Zn (e.g., Küpper et al., 1999, 2001; Frey et al., 2000; Lombi et al., 2002; Carr et al., 2003; Bhatia et al., 2004; Bidwell et al., 2004; Broadhurst et al., 2004; Cosio et al., 2005; Freeman et al., 2006). The approximate volume of this storage site multiplied by the metal concentration in it (data, e.g., for $\mathrm{Zn}$ from Küpper et al., 2009) indicates that about $70 \%$ of the total accumulated zinc in mature leaves is stored in the epidermis of $N$. caerulescens, and it is likely similar for most other species investigated by the other authors listed above. If the storage capacity of the epidermis is exceeded, enhanced storage seems to occur in the mesophyll (Küpper et al., 2001). This leads to inhibition of photosynthesis especially in those cells that accumulate most of the toxic metal (Küpper et al., 2007).

In the vacuoles of the epidermal metal storage cells, heavy metal concentrations of several hundred millimoles per liter can be reached (Küpper et al., 2001, Küpper et al., 2009), which already indicated that hyperaccumulation must involve active pumping of the metals into specific storage sites. The alternative hypothesis that the metal enrichment in the epidermis is caused by the transpiration stream (i.e., influx of metal-containing water into the epidermis, and evaporation of the water) could be excluded by a study on epidermal protoplasts. The drastically different cadmium uptake rates into epidermal storage cells compared to mesophyll cells in this study clearly showed that the epidermal accumulation is due to differences in active metal transport and not differences in passive mechanisms like transpiration stream transport or cell wall adhesion (Leitenmaier and Küpper, 2011).

Furthermore, it turned out that the transport over the cytoplasmic membrane is faster than the sequestration into the vacuole, making the latter the rate-limiting step in epidermal accumulation. Altogether, it seems likely that the transport steps over the plasma and tonoplast membranes of leaf epidermal storage cells are driving forces behind the hyperaccumulation phenotype (Leitenmaier and Küpper, 2011). Protein families involved in vacuolar sequestration may be the Nramp's (natural resistance-associated macrophage proteins), CDF's (cation diffusion facilitator), and CAX's (cation exchanger; reviewed by Hall and Williams, 2003) as well as CPx-type ATPases. Until now, already several transporters for vacuolar sequestration of zinc (and possibly cadmium) and nickel have been investigated and could be partially characterized (Van der Zaal et al., 1999; Desbrosses-Fonrouge et al., 2005; Elbaz et al., 2006; Haydon and Cobbett, 2007; Morel et al., 2009). Several CDF transporters for vacuolar sequestration of $\mathrm{Zn}$ (and possibly 
$\mathrm{Cd}$ and $\mathrm{Co}$ ) have been characterized, all are homologous, almost identical in sequence. These are MTP1, ZAT, and ZTP (Van der Zaal et al., 1999; Assunção et al., 2001; Becher et al., 2004; Dräger et al., 2004). The Arabidopsis thaliana homolog of this protein, AtMTP1, has been shown to mediate $\mathrm{Zn}$ detoxification and leaf $\mathrm{Zn}$ accumulation and it is known to be localized in the vacuolar (tonoplast) membrane (Desbrosses-Fonrouge et al., 2005). Due to the chemical similarity of cadmium and zinc, transporters designed for $\mathrm{Zn}$ inevitably will transport $\mathrm{Cd}$ as well for purely chemical reasons. MHX, a homolog of an Arabidopsis thaliana vacuolar metal (Fe, $\mathrm{Mg}, \mathrm{Zn}$ ) versus proton exchanger and member of the CDF protein family, was found to be highly expressed in the leaf vacuolar membrane of Arabidopsis halleri (Elbaz et al., 2006).

HMA3, a CPX- $\left(=\mathrm{P}_{1 \mathrm{~B}}\right)$-type heavy metal ATPase, was found to mediate leaf vacuolar storage of $\mathrm{Cd}, \mathrm{Co}, \mathrm{Pb}$, and $\mathrm{Zn}$ in Arabidopsis thaliana (Morel et al., 2009). The strongly elevated expression of HMA3 was shown to play a decisive role in $\mathrm{Cd}$ accumulation not only in N. caerulescens (Ueno et al., 2011b), but also in rice (Ueno etal., 2010, 2011a), reconfirming also the importance of the sequestration into vacuoles for the hyperaccumulation phenotype. However, the reported effects of the vacuolar sequestration on shoot metal concentrations as mediated by HMA3 are opposite in rice compared to N. caerulescens, because the localization of this expression is different. In rice, HMA3 sequesters Cd into root vacuoles, diminishing the $\mathrm{Cd}$ available for transport into the shoots (Ueno et al., 2010). In N. caerulescens, in contrast, it was shown to be expressed highly expressed also in the shoots, thus sequestering Cd there (Ueno et al., 2011b). For purely biophysical reasons (transport equilibria), this will cause enhanced xylem unloading in the shoots, and thus enhanced root-shoot translocation (i.e., a sink-driven transport).

The natural overexpression of NRAMPs was identified both in rice and in N. caerulescens to play an important role in Cd tolerance and possibly Cd accumulation (Oomen et al., 2009; Wei et al., 2009 and Takahashi et al., 2011).

Also at this final step, $\mathrm{Al}$ represents an exception: in the best known $\mathrm{Al}$ hyperaccumulator, Camellia sinensis (tea), $\mathrm{Al}$ is accumulated mostly in the cell walls, with very low concentrations inside the cells even when the samples are properly prepared to prevent artefactual cell wall localization (Carr et al., 2003).

\section{EXCEPTION: STORAGE IN THE MESOPHYLL}

Although the final storage of metals in large epidermal cells is a typical phenomenon in most hyperaccumulators and for most hyperaccumulated metals, there are also exceptions. In the $\mathrm{Zn}$ hyperaccumulator Arabidopsis halleri, accumulating cadmium to a limited extent as well, except for a few trichomes epidermal cells are rather small. Therefore, despite their high concentrations with almost all the $\mathrm{Zn}$ and $\mathrm{Cd}$ being accumulated in a narrow ring in the trichome base, epidermal cells contribute only a minor proportion to total storage of $\mathrm{Cd}$ and $\mathrm{Zn}$ in this species while most of the Cd is stored in the photosynthetic mesophyll (Küpper et al., 2000). Although Arabidopsis halleri still accumulates Cd in the hyperaccumulation range, this may be the reason why it suffers from toxicity at much lower $\mathrm{Cd}$ concentrations (in the nutrient solution and inside the plant) than the strongest known Cd hyperaccumulator, N. caerulescens, ultimately limiting $\mathrm{Cd}$ accumulation in Arabidopsis halleri: $\mathrm{Cd}$ accumulation in the mesophyll represents a danger for Cd-induced inhibition of photosynthesis (Küpper et al., 2007). A seemingly similar situation was recently reported for the $\mathrm{Cd} / \mathrm{Zn}$ hyperaccumulator S. alfredii (Yang et al., 2004), where Cd is accumulated in the mesophyll of leaves beside the pith and cortex of stems (Tian et al., 2011). Comparing this to other hyperaccumulators, however, it has to be kept in mind that $S$. alfredii as a Crassulaceae, has rather thick, succulent leaves, which means it has exceptionally large vacuoles in the mesophyll, making Cd storage there safer than it would be in regular sized mesophyll cells as they occur in N. caerulescens or Arabidopsis halleri. Another exception in the sense of hyperaccumulation in the mesophyll instead of the epidermis is manganese. In Mn-hyperaccumulating (Gossia bidwillii, Myrtaceae; Virotia neurophylla, Proteaceae) as well as strongly accumulating species (Macadamia integrifolia, $M$. tetraphylla (Proteaceae), it has been shown not to be translocated into the epidermis but to be primarily sequestrated into multiple palisade cell layers (the mesophyll), which contain photosynthetically active cells (Fernando et al., 2006a,b). However, in one accumulating species, Grevillea exul (Proteaceae), Fernando et al. (2008) showed a higher manganese content in the epidermal tissues, compared to the photosynthetic active tissues. The latter authors furthermore discussed that the translocation into photosynthetic active tissues might be due to their high need for manganese as part of the active center of the oxygen-evolvingcomplex (OEC). The sequestration into vacuoles, no matter if they are located in a storage cell or not and also independent of the type of metal, is always a transport against the concentration gradient and therefore needs an active transport system (Salt and Wagner, 1993, for a recent review see Martinoia et al., 2012).

\section{REFERENCES}

Ahner, B. A., Wei, L., Oleson, J. R., and Ogura, N. (2002). Glutathione and other low molecular weight thiols in marine phytoplankton under metal stress. Mar. Ecol. Prog. Ser. 232, 93-103. doi: 10.3354/ meps 232093

Andresen, E., Mattusch, J., Wellenreuther, G., Thomas, G., Arroyo Abad, U., and Küpper, H. (2013). Different strategies of cadmium detoxification in the submerged macrophyte Ceratophyllum demersum L. Metallomics. doi: 10.1039/C3MT00088E [Epub ahead of print].

Assunção, A. G. L., Costa Martins, P. D. A., De Folter, S., Vooijs, R., Schat, H., and Aarts, M. G. M. (2001). Elevated expression of metal transporter genes in three accessions of the metal hyperaccumulator Thlaspi caerulescens. Plant Cell Environ. 24, 217226. doi: 10.1046/j.1365-3040.2001. 00666.x
Audry, S., Schafer, J., Blanc, G. and Jouanneau, J. M. (2004). Fiftyyear sedimentary record of heavy metal pollution $(\mathrm{Cd}, \mathrm{Zn}, \mathrm{Cu}$, $\mathrm{Pb})$ in the Lot River reservoirs (France). Environ. Pollut. 132, 413-426. doi: 10.1016/j.envpol.2004. 05.025

Baker, A. J. M. (1981). Accumulators and excluders-strategies in the response of plants to heavy metals. J. Plant Nutr. 3, 643-654. doi: $10.1080 / 01904168109362867$
Barnes, A., Bale, J., Constantinidou, C., Ashton, P., Jones, A., and Pritchard, J. (2004). Determining protein identity from sieve element sap in Ricinus communis L. by quadrupole time of flight (Q-TOF) mass spectrometry. J. Exp. Bot. 55, 1473-1481. doi: 10.1093/jxb/erh161

Becher, M., Talke, I. N., Krall, L., and Krämer, U. (2004). Cross-species microarray transcript profiling reveals high constitutive expression of metal homeostasis genes in 
shoots of the zinc hyperaccumulator Arabidopsis halleri. Plant J. 37, 251-268. doi: 10.1046/j.1365-313X. 2003.01959.x

Beneš, I., Schreiber, K., Ripperger, H., and Kircheiss, A. (1983). Metal complex formation by nicotianamine, a possible phytosiderophore. Experientia 39, 261-262.

Bernard, C., Roosens, N., Czernic, P., Lebrun, M., and Verbruggen, N. (2004). A novel CPx-ATPase from the cadmium hyperaccumulator Thlaspi caerulescens. FEBS Lett. 569, 140-148. doi: 10.1016/j.febslet.2004.05.036

Bert, V., Meerts, P., Saumitou-Laprade, P., Salis, P., Gruber, W., and Verbruggen, N. (2003). Genetic basis of Cd tolerance and hyperaccumulation in Arabidopsis halleri. Plant Soil 249, 9-18.

Bhatia, N. P., Walsh, K. B., Orlic, I., Siegele, R., Ashwath, N., and Baker, A. J. M. (2004). Studies on spatial distribution of nickel in leaves and stems of the metal hyperaccumulator Stackhousia tryonii using nuclear microprobe (micro-PIXE) and EDXS techniques. Funct. Plant Biol. 31, 1061-1074. doi: 10.1071/FP03192

Bidwell, S. D., Crawford, S. A., Woodrow, I. E., Summer-Knudsen, J., and Marshal, A. T. (2004). Sub-cellular localization of $\mathrm{Ni}$ in the hyperaccumulator Hybanthus floribundus (Lindley) F. Muell. Plant Cell Environ. 27, 705716. doi: 10.1111/j.0016-8025. 2003.01170.x

Blum, R., Beck, A., Korte, A., Stengel, A., Letzel, T., Lendzian, K., etal. (2007). Function of phytochelatin synthase in catabolism of glutathione-conjugates. Plant J. 49, 740-749. doi: 10.1111/j.1365313X.2006.02993.x

Boyd, R. S., Davis, M. A., Wall, M. A., and Balkwill, K. (2002). Nickel defends the South African hyperaccumulator Senecio coronatus (Asteraceae) against Helix aspersa (Mollusca: Pulmonidae). Chemoecology 12, 91-97. doi: 10.1007/s00049002-8331-3

Boyd, R. S., and Martens, S. N. (1994). Nickel hyperaccumulated by Thlaspi montanum var. montanum is acutely toxic to an insect herbivore. Oikos 70 , 21-25.

Broadhurst, C. L., Chaney, R. L., Angle, J. S., Erbe, E. F., and Maugel, T. K. (2004). Nickel localization and response to increasing $\mathrm{Ni}$ soil levels in leaves of the Ni hyperaccumulator Alyssum murale. Plant Soil 265, 225-242. doi: 10.1007/s11104-0050974-8
Brooks, R. R. (1998). "Geobotany and hyperaccumulators," in Plants that Hyperaccumulate Heavy Metals, ed. R. R. Brooks (Wallingford, UK: CAB International), 55-94.

Brooks, R. R., Lee, J., Reeves, R. D., and Jaffre, T. (1977). Detection of nickeliferous rocks by analysis of herbarium species of indicator plants. $J$. Geochem. Explor. 7, 49-57.

Buchanan-Wollaston, V. (1994). Isolation of cDNA clones for genes that are expressed during leaf senescence in Brassica napus. Plant Physiol. 105, 839-846. doi: 10.1104/pp.105.3.839

Buchauer, M. J. (1973). Contamination of soil and vegetation near a zinc smelter by zinc, cadmium, copper, and lead. Environ. Sci. Technol. 7 131-135. doi: 10.1021/es60074a004

Byrd, J., Berger, R. M., McMillin, D. R., Wright, C. F., Hamer, D., and Winge, D. R. (1988). Characterization of the copper-thiolate cluster in yeast metallothionein and two truncated mutants. J. Biol. Chem. 263, 6688-6694.

Calderone, V., Dolderer, B., Hartmann, H. J., Echner, H., Luchinat, C., Del Bianco, C., et al. (2005). The crystal structure of yeast copper thionein: the solution of a long-lasting enigma. Proc. Natl. Acad. Sci. U.S.A. 102, 5156. doi: 10.1073/pnas.0408254101

Callahan, D. L., Baker, A. J. M., Kolev, S. D., and Wedd, A. G. (2006). Metal ion ligands in hyperaccumulating plants. J. Biol. Inorg. Chem. 11, 2-12. doi: 10.1007/s00775-005-0056-7

Carr, H. P., Lombi, E., Küpper, H., McGrath, S. P., and Wong, M. H. (2003). Accumulation and distribution of aluminium and other elements in tea (Camellia sinensis) leaves. Agronomie 23, 705-710. doi: 10.1051/agro:2003045

Carter, C., Pan, S., Zouhar, J., Avila, E. L., Girke, T., and Raikhel, N. V. (2004). The vegetative vacuole proteome of Arabidopsis thaliana reveals predicted and unexpected proteins. Plant Cell 16, 3285-3303. doi: 10.1105/tpc.104.027078

Chaney, R. L., Angle, J. S., Broadhurst, C. L., Peters, C. A., Tappero, R. V., and Sparks, D. L. (2007). Improved understanding of hyperaccumulation yields commercial phytoextraction and phytomining technologies. J. Environ. Qual. 36, 1429-1443. doi: 10.2134/jeq2006. 0514

Chaney, R. L., Angle, J. S., McIntosh, M. S., Reeves, R. D., Li, Y. M., Brewer, E. P., et al. (2005). Using hyperaccumulator plants to phytoextract soil $\mathrm{Ni}$ and Cd. Z. Naturforsch. C 60, 190-198.
Chisholm, J. E., Jones, G. C., and Purvis, O. W. (1987). Hydrated copper oxalate, moolooite, in lichens. Mineralog. Mag. 51, 715718. doi: 10.1180/minmag.1987.051 363.12

Clemens, S., Bloss, T., Vess, C., Neumann, D., Nies, D., and Zur Nieden, U. (2002). A transporter in the endoplasmic reticulum of Schizosaccharomyces pombe cells mediates zinc storage and differentially affect transition metal tolerance. J. Biol. Chem. 277, 18215-18221. doi: 10.1074/jbc.M201031200

Cobbett, C., and Goldsbrough, P. (2002). Phytochelatins and metallothioneins: roles in heavy metal detoxification and homeostasis. Ann Rev. Plant Biol. 53, 159-182.

Cosio, C., DeSantis, L., Frey, B. Diallo, S., and Keller, C. (2005). Distribution of cadmium in leaves of Thlaspi caerulescens. J. Exp. Bot. 56, 765-775. doi: 10.1093/jxb/ eri062

Craciun, A. R., Meyer, C. L., Chen, J., Roosens, N., De Groodt, R., Hilson, P., et al. (2012). Variation in HMA4 gene copy number and expression among Noccaea caerulescens populations presenting different levels of Cd tolerance and accumulation. J. Exp. Bot. 63, 4179-89. doi: 10.1093/jxb/ers104

Deinlein, U., Weber, M., Schmidt, H., Rensch, S., Trampczynska, A., Hansen, T. H., etal. (2012). Elevated nicotianamine levels in Arabidopsis halleri roots play a key role in zinc hyperaccumulation. Plant Cell 24, 708-723. doi: 10.1105/tpc.111.095000

Desbrosses-Fonrouge, A. G., Voigt, K., Schroder, A., Arrivault, S., Thomine, S., and Krämer, U. (2005). Arabidopsis thaliana MTP1 is a $\mathrm{Zn}$ transporter in the vacuolar membrane which mediates $\mathrm{Zn}$ detoxification and drives leaf $\mathrm{Zn}$ accumulation. FEBS Lett. 579, 4165-4174. doi: 10.1016/j.febslet. 2005.06.046

Dou, C. M., Fu, X. P., Chen, X. C., Shi, J. Y., and Chen, Y. X. (2009). Accumulation and detoxification of manganese in hyperaccumulator Phytolacca americana. Plant Biol. 11, 664-670. doi: 10.1111/j.1438-8677.2008.00163.x Dräger, D. B., Desbrosses-Fonrouge, A. G., Krach, C., Chardonnens, A. N., Meyer, R. C., Saumitou-Laprade, P., et al. (2004). Two genes encoding Arabidopsis halleri MTP1 metal transport proteins co-segregate with zinc tolerance and account for high MTP1 transcript levels. Plant J. 39, 425-439.
Duvigneaud, P. (1958). La végétation du Katanga et de ses sols métalliferes. Bull. Soc. Roy. Bot. Belg. 90, 127-286.

Ebbs, S., Lau, I., Ahner, B., and Kochian, L. V. (2002). Phytochelatin synthesis is not responsible for $\mathrm{Cd}$ tolerance in the $\mathrm{Zn} / \mathrm{Cd}$ hyperaccumulator Thlaspi caerulescens (J.\& C. Presl). Planta 214, 635-640. doi: $10.1007 / \mathrm{s} 004250100650$

Elbaz, B., Shoshani-Knaani, N., DavidAssael, O., Mizrachy-Dagri, T., Mizrahi, K., Saul, H., et al. (2006). High expression in leaves of the zinc hyperaccumulator Arabidopsis halleri of AhMHX, a homolog of an Arabidopsis thaliana vacuolar metal/proton exchanger. Plant Cell Environ. 29, 1179-1190. doi: 10.1111/j.1365-3040.2006.01500.x

Fergusson, J. E., Hayes, R. W., Yong, T. S., and Thiew, S. H. (1980). Heavy metal pollution by traffic in Christchurch, New Zealand: lead and cadmium content of dust, soil, and plant samples. N. Z. J. Sci. 23, 293-310.

Fernandez, L. R., Vandenbussche, G., Roosens, N., Govaerts, C., Goormaghtigh, E., and Verbruggen, N. (2012). Metal binding properties and structure of a type III metallothionein from the metal hyperaccumulator plant Noccaea caerulescens. Biochim. Biophys. Acta 1824, 1016-1023. doi: 10.1016/j.bbapap.2012.05.010

Fernando, D. R., Bakkaus, E. J., Perrier, N., Baker, A. J. M., Woodrow, I. E., Batianoff, G. N., et al. (2006a). Manganese accumulation in the leaf mesophyll of four tree species: a PIXE/EDAX localization study. New Phytol. 171, 751758. doi: 10.1111/j.1469-8137.2006. 01783.x

Fernando, D. R., Batianoff, G. N., Baker, A. J. M., and Woodrow, I. E. (2006b). In vivo localisation of manganese in the hyperaccumulator Gossia bidwillii (Benth.) N. Snow \& Guymer (Myrtaceae) by cryoSEM/EDAX. Plant Cell Environ. 29, 1012-1020.

Fernando, D. R., Marshall, A. T., Gouget, B., Carrière, M., Collins, R. N., Woodrow, I. E., et al. (2008). Novel pattern of foliar metal distribution in a manganese hyperaccumulator. Funct. Plant Biol. 35, 193-200. doi: 10.1071/FP07272

Fernando, D. R., Mizuno, T., Woodrow, I. E., Baker, A. J., and Collins, R. N. (2010). Characterization of foliar manganese (Mn) in $\mathrm{Mn}$ (hyper)accumulators using X-ray absorption spectroscopy. New Phytol. 188, 1014-1027. doi: 10.1111/j.14698137.2010.03431.x 
Fomina, M., Hillier, S., Charnock, J. M., Melville, K., Alexander, I. J., and Gadd, G. M. (2005). Role of oxalic acid overexcretion in transformations of toxic metal minerals by Beauveria caledonica. Appl. Environ. Microbiol. 71, 371-381. doi: 10.1128/AEM.71.1.371-381.2005

Frausto da Silva, J. J. R., and Williams, R. J. P. (2001). The Biological Chemistry of the Elements: The Inorganic Chemistry of Life. Oxford: Oxford University Press.

Freeman, J. L., Persans, M. W., Nieman, K., Albrecht, C., Peer, W., Pickering, I. J., et al. (2004). Increased glutathione biosynthesis plays a role in nickel tolerance in Thlaspi nickel hyperaccumulators. Plant Cell 16, 2176-2191. doi: 10.1105/tpc.104.023036

Freeman, J. L., Zhang, L. H., Marcus, M. A., Fakra, S., McGrath, S. P., and Pilon-Smits, E. A. (2006). Spatial imaging, speciation, and quantification of selenium in the hyperaccumulator plants Astragalus bisulcatus and Stanleya pinnata. Plant Physiol. 142, 124-134. doi: 10.1104/pp.106.081158

Freisinger, E. (2011). Structural features specific to plant metallothioneins. $J$. Biol. Inorg. Chem. 16, 1035-1045. doi: 10.1007/s00775-011-0801-z

Frérot, H., Faucon, M. P., Willems, G., Godé, C., Courseaux, A., Darracq, A., et al. (2010). Genetic architecture of zinc hyperaccumulation in Arabidopsis halleri: the essential role of QTL x environment interactions. New Phytol. 187, 355-367. doi: 10.1111/j.1469-8137.2010.03295.x

Frey, B., Keller, C., Zierold, K., and Schulin, R. (2000). Distribution of $\mathrm{Zn}$ in functionally different epidermal cells of the hyperaccumulator Thlaspi caerulescens. Plant Cell Environ. 23, 675-687. doi: 10.1046/j.1365-3040.2000.00590.x

Garcia-Hernandez, M., Murphy, A., and Taiz, L. (1998). Metallothioneins 1 and 2 have distinct but overlapping expression patterns in Arabidopsis. Plant Physiol. 118, 387-397. doi: 10.1104/pp.118.2.387

Grill, E., Löffler, S., Winnacker, E. L., and Zenk, M. H. (1989). Phytochelatins, the heavy-metalbinding peptides of plants, are synthesized from glutathione by a specific $\gamma$-glutamylcysteine dipeptidyl transpeptidase (phytochelatin synthase). Proc. Natl. Acad. Sci. U.S.A. 86, 6838-6842. doi: 10.1073/pnas.86.18.6838

Grill, E., Winnacker, E. U., and Zenk, M. H. (1985). Phytochelatins: the principal heavy-metal complexing peptides of higher plants. Science 230, 674-676. doi: 10.1126/science.230.4726.674

Guerinot, M. L. (2000). The ZIP family of metal transporters. Biochim. Biophys. Acta 1465, 190 198. doi: 10.1016/S0005-2736(00) 00138-3

Guo, W. J., Bunditha, W., and Goldsbrough, P. B. (2003). Characterization of the Arabidopsis metallothionein gene family: tissuespecific expression and induction during senescence and in response to copper. New Phytol. 159, 369 381. doi: 10.1046/j.1469-8137.2003. 00813.x

Hale, K. L., McGrath, S. P., Lombi, E., Stack, S. M., Terry, N., Pickering, I. J., etal. (2001). Molybdenum sequestration in Brassica species. A role for anthocyanins? Plant Physiol. 126, 1391-1402. doi: 10.1104/pp.126.4.1391

Hall, J. L., and Williams, L. E. (2003). Transition metal transporters in plants. J. Exp. Bot. 54, 2601-2613. doi: $10.1093 / j x b / e r g 303$

Hanikenne, M., Talke, I. N., Haydon, M. J., Lanz, C., Nolte, A., Motte, P., etal. (2008). Evolution of metal hyperaccumulation required cis-regulatory changes and triplication of HMA4. Nature 453, 391-396. doi: 10.1038/nature 06877

Hanson, B., Garifullina, G. F., Lindblom, S. D., Wangeline, A., Ackley, A., Kramer, K., et al. (2003). Selenium accumulation protects Brassica juncea from invertebrate herbivory and fungal infection. New Phytol. 159, 461-469. doi: 10.1046/j.1469-8137. 2003.00786.x

Hartley-Whitaker, J., Ainsworth, G., Vooijs, R., Ten Bookum, W., Schat, H., and Meharg, A. A. (2001). Phytochelatins are involved in differential arsenate tolerance in Holcus lanatus. Plant Physiol. 126, 299-306. doi: 10.1104/pp.126.1.299

Haydon, M. J., and Cobbett, C. S (2007). A novel major facilitator superfamily protein at the tonoplast influences zinc tolerance and accumulation in Arabidopsis. Plant Physiol. 143, 1705-1719. doi: 10.1104/pp.106. 092015

He, Z. L., Fan, J. H., Yang, X. E. and Stoffella, P. J. (2009). "Effect of copper contamination on soil quality and transport to the environment," in Progress in Environmental Science and Technology, Vol II, PTS A and B, eds S. C. Li, Y. J. Wang, F. X. Cao, P. Huang, and Y. Zhang (Marrickville: Science Press) 1892-1898.
Heise, J., Krejci, S., Miersch, J., Krauss, G. J., and Humbeck, K. (2007) Gene expression of metallothioneins in barley during senescence and heavy metal treatment. Crop Sci. 47, 1111-1118. doi: 10.2135/cropsci2006.03.0183

Howden, R., Goldsbrough, P. B., Andersen, C. R., and Cobbett, C. S. (1995). Cadmium-sensitive cad7 mutants of Arabidopsis thaliana are phytochelatin deficient. Plant Physiol. 107, 1059-1066. doi: 10.1104/pp.107.4.1059

Hung, Y. H., Layton, M. J., Voskoboinik, I., Mercer, J. F. B., and Camakaris, J. (2007). Purification and membrane reconstitution of catalytically active Menkes copper-transporting P-type ATPase (MNK; ATP7A). Biochem. J. 401, 569-579.

Irtelli, B., Petrucci, W. A., and NavarriIzzo, F. (2009). Nicotianamine and histidine/proline are, respectively, the most important copper chelators in xylem sap of Brassica carinata under conditions of copper deficiency and excess. J. Exp. Bot. 60, 269-277. doi: 10.1093/jxb/ern286

Jhee, E. M., Boyd, R. S., and Eubanks, M. D. (2005). Nickel hyperaccumulation as an elemental defense of Streptanthus polygaloides (Brassicaceae): influence of herbivore feeding mode. New Phytol. 168, 331-343. doi: 10.1111/j.1469-8137.2005.01504.x

Jiang, R. F., Ma, D. Y., Zhao, F. J., and McGrath, S. P. (2005) Cadmium hyperaccumulation protects Thlaspi caerulescens from leaf feeding damage by thrips (Frankliniella occidentalis). New Phytol. 167, 805814. doi: 10.1111/j.1469-8137.2005 01452.x

Kawashima, I., Kennedy, T. D., Chino M., and Lane, B. G. (1992). Wheat Ec metallothionein genes: like mammalian $\mathrm{Zn} 2+$ metallothionein genes wheat $\mathrm{Zn} 2+$ metallothionein genes are conspicuously expressed during embryogenesis. Eur. J. Biochem. 209, 971-976. doi: 10.1111/j.1432 1033.1992.tb17370.x

Ke, W., Xiang, Z., and Chen, S. (2007). Effects of copper and mineral nutrition on growth, copper accumulation and mineral element uptake in two Rumex japonicus populations from a copper mine and an uncontaminated field sites. Environ. Exp. Bot. 59, 59-67. doi: 10.1016/j.envexpbot.2005.10.007

Kerkeb, L., and Krämer, U. (2003). The role of free histidine in xylem loading of nickel in Alyssum lesbiacum and Brassica juncea. Plant Physiol. 131, 716-724. doi: 10.1104/pp102. 010686
Krämer, U. (2010). Metal hyperaccumulation in plants. Annu. Rev. Plant Biol. 61, 517-534. doi: 10.1146/annurev-arplant-042809-11 2156

Krämer, U., Cotterhowells, J. D., Charnock, J. M., Baker, A. J. M., and Smith, J. A. C. (1996). Free histidine as a metal chelator in plants that accumulate nickel. Nature 379, 635-638. doi: $10.1038 / 379635 \mathrm{a} 0$

Küpper, H., and Kochian, L. V. (2010). Transcriptional regulation of metal transport genes and mineral nutrition during acclimatization to cadmium and zinc in the Cd/Zn hyperaccumulator, Thlaspi caerulescens (Ganges population). New Phytol. 185, 114-129. doi: 10.1111/j.1469-8137.2009.03051.x

Küpper, H., and Kroneck, P. M. H. (2005). "Heavy metal uptake by plants and cyanobacteria," in Metal Ions in Biological Systems, Vol. 44, eds A. Sigel, H. Sigel, and R. K. O. Sigel (New York: Marcel Dekker, Inc.), 97-142.

Küpper, H., and Kroneck, P. M. H. (2007). "Nickel in the environment and its role in the metabolism of plants and cyanobacteria," in Metal Ions in Life Sciences, Vol. 2, eds A. Sigel, H. Sigel, and R. K. O. Sigel (Dordrecht: Springer), 31-62.

Küpper, H., Küpper, F., and Spiller, M. (1996). Environmental relevance of heavy metal substituted chlorophylls using the example of water plants. J. Exp. Bot. 47, 259-266. doi: 10.1093/jxb/47.2.259

Küpper, H., and Leitenmaier, B. (2013). "Cadmium-accumulating plants," in Metal Ions in Life Sciences, Vol. 11, eds A. Sigel, H. Sigel, and R. K. O. Sigel (Dordrecht: Springer), 373-394.

Küpper, H., Lombi, E., Zhao, F. J., and McGrath, S. P. (2000). Cellular compartmentation of Cadmium and Zinc in relation to other elements in the hyperaccumulator Arabidopsis halleri. Planta 212, 75-84.

Küpper, H., Lombi, E., Zhao, F. J., Wieshammer, G., and McGrath, S. P. (2001). Cellular compartmentation of nickel in the hyperaccumulators Alyssum lesbiacum, Alyssum bertolonii, and Thlaspi goesingense. J. Exp. Bot. 52, 2291-2300. doi: 10.1093/jexbot/52.365.2291

Küpper, H., Mijovilovich, A., Götz, B., Küpper, F. C., and Meyer-Klaucke, W. (2009). Complexation and toxicity of copper in higher plants (I): Characterisation of copper accumulation, speciation and toxicity in Crassula helmsii as a new copper hyperaccumulator. Plant Physiol. 151, 702-714. doi: $10.1104 /$ pp.109.139717 
Küpper, H., Mijovilovich, A., MeyerKlaucke, W., and Kroneck, P. M. H. (2004). Tissue- and agedependent differences in the complexation of cadmium and zinc in the $\mathrm{Cd} / \mathrm{Zn}$ hyperaccumulator Thlaspi caerulescens (Ganges ecotype) revealed by X-ray absorption spectroscopy. Plant Physiol. 134, 748-757. doi: http://dx.doi. org/10.1104/pp.103.032953

Küpper, H., Parameswaran, A., Leitenmaier, B., Trtílek, M., and Šetlík, I. (2007). Cadmium-induced inhibition of photosynthesis and long-term acclimation to cadmium stress in the hyperaccumulator Thlaspi caerulescens. New Phytol. 175, 655-674. doi: 10.1111/j.14698137.2007.02139.x

Küpper, H., Zhao, F. J., and McGrath, S. P. (1999). Cellular compartmentation of zinc in leaves of the hyperaccumulator Thlaspi caerulescens. Plant Physiol. 119, 305-311. doi: 10.1104/pp.119.1.305

Lane, T. W., and Morel, F. M. M. (2000). A biological function for cadmium in marine diatoms. Proc. Nat. Acad. Sci. U.S.A. 97, 4627-4631. doi: 10.1073/pnas. 090091397

Lasat, M. M., Baker, A. J. M. and Kochian, L. V. (1996). Physiological characterization of root $\mathrm{Zn} 2+$ absorption and translocation to shoots in $\mathrm{Zn}$ hyperaccumulator and nonaccumulator species of Thlaspi. Plant Physiol. 112, 17151722.

Lasat, M. M., Baker, A. J. M., and Kochian, L. V. (1998). Altered Zn compartmentation in the root symplasm and stimulated $\mathrm{Zn}$ absorption into the leaf as mechanisms involved in $\mathrm{Zn}$ hyperaccumulation in Thlaspi caerulescens. Plant Physiol. 118, 875-883. doi: 10.1104/pp.118. 3.875

Leitenmaier, B., and Küpper, H. (2011). Cadmium uptake and sequestration kinetics in individual leaf cell protoplasts of the $\mathrm{Cd} / \mathrm{Zn}$ hyperaccumulator Thlaspi caerulescens. Plant Cell Environ. 34, 208219. doi: 10.1111/j.1365-3040.2010. 02236.x

Leitenmaier, B., Witt, A., Witzke, A., Stemke, A., Meyer-Klaucke, W. Kroneck, P. M. H., et al. (2011). Biochemical and biophysical characterisation yields insights into the mechanism of a Cd/Zn transporting ATPase purified from the hyperaccumulator plant Thlaspi caerulescens. Biochim. Biophys. Acta 1808, 25912599. doi: 10.1016/j.bbamem.2011. 05.010
Li, M. S., Luo, Y. P., and Su, Z. Y. (2007). Heavy metal concentrations in soils and plant accumulation in a restored manganese mineland in Guangxi, South China. Environ. Pollut. 147, 168-175. doi: 10.1016/j.envpol.2006.08.006

Li, T., Xu, Z., Han, X., Yang, X., and Sparks, D. L. (2012). Characterization of dissolved organic matter in the rhizosphere of hyperaccumulator Sedum alfredii and its effect on the mobility of zinc. Chemosphere 88, 570576. doi: 10.1016/j.chemosphere. 2012.03.031

Liao, M. T., Hedley, M. J., Woolley, D. J., Brooks, R. R., and Nichols, M. A. (2000). Copper uptake and translocation in chicory (Cichorium intybus L. cv Grasslands Puna) and tomato (Lycopersicon esculentum Mill. cv Rondy) plants grown in NFT system. II. The role of nicotianamine and histidine in xylem sap copper transport. Plant Soil 223, 243-252.

Liu, H., Probst, A., and Liao, B. (2005). Metal contamination of soils and crops affected by the Chenzhou lead/zinc mine spill (Hunan, China). Sci. Total Environ. 339, 153 166. doi: 10.1016/j.scitotenv.2004. 07.030

Liu, M. Q., Yanai, J., Jiang, R. F., Zhang, F., McGrath, S. P. and Zhao, F. J. (2008). Does cadmium play a physiological role in the hyperaccumulator Thlaspi caerulescens? Chemosphere 71, 12761283. doi: 10.1016/j.chemosphere. 2007.11.063

Loebus, J., Peroza, E. A., Blüthgen, N., Fox, T., Meyer-Klaucke, W., Zerbe, O. et al. (2011). Protein and metal cluster structure of the wheat metallothionein domain $\mathrm{y}-\mathrm{Ecl}$ : the second part of the puzzle. J. Biol. Inorg. Chem. 16, 683-694. doi: 10.1007/s00775-0110770-2

Lombi, E., Zhao, F. J., Fuhrmann, M., Ma, L.Q., and McGrath, S. P. (2002). Arsenic distribution and speciation in the fronds of the hyperaccumulator Pteris vittata. New Phytol. 156, 195-203. doi: 10.1046/j.14698137.2002.00512.x

Lovy, L., Latt, D., and Sterckeman, T. (2013). Cadmium uptake and partitioning in the hyperaccumulator Noccaea caerulescens exposed to constant Cd concentrations throughout complete growth cycles. Plant Soi 362, 345-354. doi: 10.1007/s11104012-1291-7

Lu, L., Tian, S., Zhang, J., Yang, X. Labavitch, J. M., Webb, S. M., et al. (2013). Efficient xylem transport and phloem remobilization of $\mathrm{Zn}$ in the hyperaccumulator plant species Sedum alfredii. New Phytol. 198, 721731. doi: 10.1111/nph.12168

Lux, A., Martinka, M., Vaculík, M., and White, P. J. (2011). Root responses to cadmium in the rhizosphere: a review. J. Exp. Bot. 62, 21-37. doi: 10.1093/jxb/erq281

Mackie, K. A., Müller, T., and Kandeler, E. (2012). Remediation of copper in vineyards - a mini review. Environ. Pollut. 167, 16-26. doi: 10.1016/j.envpol.2012.03.023

Macnair, M. R., Bert, V., Huitson, S. B., SaumitouLaprade, P., and Petit, D. (1999). Zinc tolerance and hyperaccumulation are genetically independent characters. Proc. R. Soc. Lond. B Biol. Sci. 266, 2175-2179. doi 10.1098/rspb.1999.0905

Maitani, T., Kubota, H., Sato, K., and Yamada, T. (1996). The composition of metals bound to class III metallothionein (phytochelatin and its desglycyl peptide) induced by various metals in root cultures of Rubia tinctorum. Plant Physiol. 110, 1145 1150.

Malaisse, F., Baker, A. J. M., and Ruelle, S. (1999). Diversity of plant communities and leaf heavy metal content at Luiswishi copper/cobalt mineralization, Upper Katanga, Dem. Rep. Congo. Biotechnol. Agron. Soc. Environ. 3, 104-114.

Mari, S., Gendre, D., Pianelli, K., Ouerdane, L., Lobinski, R., Briat, J. F., et al. (2006). Root-to-shoot long-distance circulation of nicotianamine and nicotianamine-nickel chelates in the metal hyperaccumulator Thlaspi caerulescens. J. Exp. Bot. 57, 4111-4122. doi: 10.1093/jxb/ erl184

Martens, S. N., and Boyd, R. S. (1994) The ecological significance of nickel hyperaccumulation: a plant chemical defense. Oecologia 98, 379-384. doi: 10.1007/BF00324227

Martínez-Alcalá, I., Hernández, L. E., Esteban, E., Walker, D. J., and Bernal, M. P. (2013). Responses of Noccaea caerulescens and Lupinus albus in trace elements-contaminated soils. Plant Physiol. Biochem. 66, 47-55. doi: 10.1016/j.plaphy.2013. 01.017

Martinoia, E., Meyer, S., De Angeli, A., and Nagy, R. (2012). Vacuolar transporters in their physiological context. Annu. Rev. Plant Biol. 63, 183-213. doi: 10.1146/annurevarplant-042811-105608

Matsumoto, H., Hirasawa, E. Morimura, S., and Takahashi, E. (1976). Localization of aluminium in tea leaves. Plant Cell Physiol. 17, 627-631.
McBride, M. B., Richards, B. K., Steenhuis, T., Russo, J. J., and Sauvé, S. (1997). Mobility and solubility of toxic metals and nutrients in soil fifteen years after sewage sludge application. Soil Sci. 162, 487-500.

Mijovilovich, A., Leitenmaier, B., Mayer-Klaucke, W., Kroneck, P. M. H., Götz, B., and Küpper, H. (2009). Complexation and toxicity of copper in higher plants II. Different mechanisms for copper vs. cadmium detoxification in the copper-sensitive cadmium/zinc hyperaccumulator Thlaspi caerulescens (Ganges ecotype). Plant Physiol. 151, 715-731. doi: 10.1104/pp.109.144675

Morel, M., Crouzet, J., Gravot, A., Auroy, P., Leonhardt, N., Vavasseur, A., et al. (2009). AtHMA3, a $\mathrm{P} 1 \mathrm{~B}-\mathrm{ATPase}$ allowing $\mathrm{Cd} / \mathrm{Zn} / \mathrm{Co} / \mathrm{Pb}$ vacuolar storage in Arabidopsis. Plant Physiol. 149, 894-904. doi: 10.1104/pp.108.130294

Neumann, D., and De Figuero, C. (2002). A novel mechanism of silicon uptake. Protoplasma 220, 59-67. doi: 10.1007/s00709-0020034-7

O'Lochlainn, S., Bowen, H. C., Fray, R. G., Hammond, J. P., King, G. J., White, P. J., et al. (2011). Tandem quadruplication of HMA4 in the Zinc $(\mathrm{Zn})$ and Cadmium (Cd) hyperaccumulator Noccaea caerulescens. PLoS ONE 6:e17814. doi: 10.1371/journal.pone.0017814

Oomen, R. J. F. J., Wu, J., Lelièvre, F., Blanchet, S., Richaud, P., BarbierBrygoo, H., et al. (2009). Functional characterisation of NRAMP3 and NRAMP4 from the metal hyperaccumulator Thlaspi caerulescens. New Phytol. 181, 637-650.

Papoyan, A., and Kochian, L. V. (2004). Identification of Thlaspi caerulescens genes that may be involved in heavy metal hyperaccumulation and tolerance. Characterization of a novel heavy metal transporting ATPase. Plant Physiol. 136, 3814-3823. doi: 10.1104/pp.104.044503

Parameswaran, A., Leitenmaier, B., Yang, M., Welte, W., Kroneck, P. M. H., Lutz, G., et al. (2007). A native $\mathrm{Zn} / \mathrm{Cd}$ transporting P1B type ATPase protein from natural overexpression in a $\mathrm{Zn} / \mathrm{Cd}$ hyperaccumulator plant. Biochem. Biophys. Res. Commun. 364, 51-56.

Pence, N. S., Larsen, P. B., Ebbs, S. D., Lasat, M. M., Letham, D. L. D., Garvin, D. F., et al. (2000). The molecular physiology of heavy metal transport in the $\mathrm{Cd} / \mathrm{Zn}$ hyperaccumulator Thlaspi caerulescens. Proc. Natl. Acad. Sci. U.S.A. 97, 4956-4960. doi: 10.1073/pnas.97.9.4956 
Peroza, E. A., and Freisinger, E. (2007). Metal ion binding properties of Triticum aestivum Ec-1 metallothionein: evidence supporting two metal thiolate clusters. J. Biol. Inorg. Chem. 12, 377-391. doi: 10.1007/s00775-007-0225-y

Pich, A., Scholz, G., and Stephan, U. W. (1994). Iron-dependent changes of heavy metals, nicotianamine, and citrate in different plant organs and in the xylem of two tomato genotypes: nicotianamine as possible copper translocator. Plant Soil 165, 189-196. doi: 10.1007/ BF00008061

Pich, A., and Scholz, I. (1996). Translocation of copper and other micronutrients in tomato plants (Lycopersicon esculentum Mill.): nicotianaminestimulated copper transport in the xylem. J. Exp. Bot. 47, 41-47. doi: 10.1093/jxb/47.1.41

Pietrini, F., Iannelli, M. A., Pasqualini, S., and Massacci, A. (2003). Interaction of cadmium with glutathione and photosynthesis in developing leaves and chloroplasts of Phragmites australis (Cav.) Trin. ex Steudel. Plant Physiol. 133, 829-837. doi: 10.1104/pp.103.026518

Polette, L. A., Gardea-Torresdey, J. L., Chianelli, R. R., George, G. N., Pickering, I. J., and Arenas, J. (2000). XAS and microscopy studies of the uptake and bio-transformation of copper in Larrea tridentata (creosote bush). Microchem. J. 65, 227236. doi: $10.1016 / \mathrm{S} 0026-265 \mathrm{X}(00)$ 00055-2

Prasad, M. N. V., and Hagemeyer, J. (eds) (1999). Heavy metal stress in plants: from molecules to ecosystems. Heidelberg: Springer.

Purvis, O. W., Pawlik-Skowronska, B., Cressey, G., Jones, G. C., Kearsley, A., and Spratt, J. (2008). Mineral phases and element composition of the copper hyperaccumulator lichen Lecanora polytropa. Mineral. Mag. 72, 607-616. doi: 10.1180/minmag.2008.072.2.607

Ribolzi, O., Valles, V., Gomez, L., and Voltz, M. (2002). Speciation and origin of particulate copper in runoff water from a Mediterranean vineyard catchment. Environ. Pollut. 117, 261-271. doi: 10.1016/S02697491(01)00274-3

Richau, K. H., Kozhevnikova, A. D., Seregin, I. V., Vooijs, R., Koevoets, P. L., Smith, J. A., et al. (2009). Chelation by histidine inhibits the vacuolar sequestration of nickel in roots of the hyperaccumulator Thlaspi caerulescens. New Phytol. 183, 106-16. doi: 10.1111/j.14698137.2009.02826.x
Rigouin, C., Nylin, E., Cogswell, A. A., Schaumlöffel, D., Dobritzsch, D. and Williams, D. L. (2013). Towards an understanding of the function of the phytochelatin synthase of Schistosoma mansoni. PLOS Negl. Trop. Dis. 7:e2037. doi: 10.1371/journal.pntd.0002037

Romic, M., and Romic, D. (2003). Heavy metals distribution in agricultural topsoils in urban area. Environ Geol. 43, 795-805.

Roosens, N. H., Bernard, C., Leplae, R., and Verbruggen, $\mathrm{N}$. (2004). Evidence for copper homeostasis function of metallothionein (MT3) in the hyperaccumulator Thlaspi caerulescens. FEBS Lett. 577, 9-16. doi: 10.1016/j.febslet.2004. 08.084

Ruyters, S., Salaets, P., Oorts, K. and Smolders, E. (2013). Copper toxicity in soils under established vineyards in Europe: a survey. Sci. Total Environ. 443, 470-477. doi: 10.1016/j.scitotenv.2012.11.001

Sachs, J. (1865). Handbuch der Experimental-Physiologie der Pflanzen. Leipzig, Germany: Verlag von Wilhelm Engelmann, 153-154, $\$ 47$.

Sagner, S., Kneer, R., Wanner, G., Cosson, J. P., Deus-Neumann, B. and Zenk, M. H. (1998). Hyperaccumulation, complexation, and distribution of nickel in Sebertia acuminata. Phytochemistry 47, 339347. doi: 10.1016/S0031-9422(97) 00593-1

Salt, D. E., Prince, R. C., Baker, A. J. M., Raskin, I., and Pickering, I. J. (1999). Zinc ligands in the metal hyperaccumulator Thlaspi caerulescens as determined using X-ray absorption spectroscopy. Environ. Sci. Technol. 33, 713-717. doi: 10.1021/ es980825x

Salt, D. E., and Wagner, G. J. (1993). Cadmium transport across tonoplast of vesicles from oat roots. Evidence for a $\mathrm{Cd} 2+/ \mathrm{H}+$ antiport activity. $J$. Biol. Chem. 268, 12297-12302.

Satofuka, H., Fukui, T., Takagi, M., Atomi, H., and Imanaka, T. (2001). Metal-binding properties of phytochelatin-related peptides. J. Inorg. Biochem. 86, 595-602. doi: 10.1016/S01620134(01)00223-9

Schat, H., Llugany, M., Vooijs, R., Hartley-Whitaker, J., and Bleeker, P. M. (2002). The role of phytochelatins in constitutive and adaptive heavy metal tolerances in hyperaccumulator and nonhyperaccumulator metallophytes. J. Exp. Bot. 53, 2381-2392. doi: 10.1093/ jxb/erf107
Scholz, G., Becker, R., Pich, A. and Stephan, U. W. (1992). Nicotianamine - a common constituent of strategy-I and strategy-II of iron acquisition by plants - a review. J. Plant Nutr. 15, $1647-$ 1665. doi: 10.1080/01904169209 364428

Shen, Z. G., Zhao, F. J., and McGrath, S. P. (1997). Uptake and transport of zinc in the hyperaccumulator Thlaspi caerulescens and the nonhyperaccumulator Thlaspi ochroleucum. Plant Cell Environ. 20, 898-906. doi: $10.1046 / j .1365-3040.1997 . d 01-$ 134.x

Takahashi, R., Bashir, K., Ishimaru, Y., Nishizawa N. K., and Nakanishi, H. (2012). The role of heavymetal ATPases, HMAs, in zinc and cadmium transport in rice. Plant Signal. Behav. 7, 1605-1607. doi: $10.4161 / \mathrm{psb} .22454$

Takahashi, R., Ishimaru, Y., Senoura, T. Shimo, H., Ishikawa, S., Arao, T., et al. (2011). The OsNRAMP1 iron transporter is involved in Cd accumulation in rice. J. Exp. Bot. 62, 4843-4850. doi: $10.1093 / \mathrm{jxb} / \mathrm{err} 136$

Talke, I. N., Hanikenne, M., and Krämer, U. (2006). Zinc dependent global transcriptional control, transcriptional deregulation, and higher gene copy number for genes in metal homeostasis in the hyperaccumulator Arabidopsis halleri. Plant Physiol. 142, 148-167. doi: 10.1104/pp.105. 076232

Tennstedt, P., Peisker, D., Böttcher, C., Trampczynska, A., and Clemens, S. (2009). Phytochelatin synthesis is essential for the detoxification of excess zinc and contributes significantly to the accumulation of zinc. Plant Physiol. 149, 938-948. doi: 10.1104/pp.108 127472

Tian, S., Lu, L., Labavitch, J., Yang, X., He, Z., Hu, H., et al. (2011). Cellular sequestration of cadmium in the hyperaccumulator plant species Sedum alfredii. Plant Physiol. 157, 1914-1925. doi: 10.1104/pp.111. 183947

Trampczynska, A., Küpper, H., MeyerKlaucke, W., Schmidt, H., and Clemens, S. (2010). Nicotianamine forms complexes with $\mathrm{Zn}(\mathrm{II})$ in vivo. Metallomics 2, 57-66. doi: 10.1039/b913299f

Ueno, D., Koyama, E., Yamaji, N. and Ma, J. F. (2011a). Physiologi$\mathrm{cal}$, genetic, and molecular characterization of a high-Cd-accumulating rice cultivar, Jarjan. J. Exp. Bot. 62 , 2265-2272. doi: 10.1093/jxb/erq383

Ueno, D., Millner, M. J., Yamaji, N., Yokosho, K., Koyama, E., Zambrono,
M. C., etal. (2011b). Elevated expression of TcHMA3 plays a key role in the extreme cadmium tolerance in a Cd-hyperaccumulating ecotype of Thlaspi caerulescens. Plant J. 66, 852-862. doi: 10.1111/j.1365313X.2011.04548.x

Ueno, D., Yamaji, N., Kono, I., Huang, C.F., Ando, T., Yano, M., et al. (2010) Gene limiting Cadmium accumulation in rice. Proc. Nat. Acad Sci. U.S.A. 107, 16500-16505. doi: 10.1073/pnas.1005396107

van de Mortel, J. E., Almar Villanueva, L., Schat, H., Kwekkeboom, J., Coughlan, S., Moerland, P. D., et al. (2006). Large expression differences in genes for iron and zinc homeostasis, stress response, and lignin biosynthesis distinguish roots of Arabidopsis thaliana and the related metal hyperaccumulator Thlaspi caerulescens. Plant Physiol. 142, 1127-1147. doi: 10.1104/pp.106.082073

van de Mortel, J. E., Schat, H., Moerland, P. D., Ver Loren van Themaat, E., van der Ent, S., Blankestijn, H., et al. (2008). Expression differences for genes involved in lignin, glutathione and sulphate metabolism in response to cadmium in Arabidopsis thaliana and the related $\mathrm{Zn} / \mathrm{Cd}$-hyperaccumulator Thlaspi caerulescens. Plant Cell Environ. 31, 301-324. doi: 10.1111/j.1365-3040.2007.01764.x

Van der Zaal, B. J., Neuteboom, L. W., Pinas, J. E., Chardonnens, A. N., Schat, H., Verkleij, J. A., et al. (1999). Overexpression of a novel Arabidopsis gene related to putative zinc-transporter genes from animals can lead to enhanced zinc resistance and accumulation. Plant Physiol. 119, 1047-1055. doi: 10.1104/pp.119.3.1047

Van Geen, A., Adkins, J. F., Boyle, E. A., Nelson, C. H., and Palanques, A. (1997). A $120 \mathrm{yr}$ record of widespread contamination from mining of the Iberian pyrite belt. Geology 25, 291-294. doi: 10.1130/00917613(1997)025<0291: AYROWC $>2$. 3.CO;2

van Hoof, N. A. L. M., Koevoets, P. L. M., Hakvoort, H. W. J., Ten Bookum, W. M., Schat, H., Verkleij, J. A. C., etal. (2001). Enhanced ATP-dependent copper efflux across the root cell plasma membrane in copper-tolerant Silene vulgaris. Physiol. Plant. 113, 225-232. doi 10.1034/j.1399-3054.2001.1130210.x Verbruggen, N., Hermans, S., and Schat, H. (2009). Molecular mechanisms of metal hyperaccumulation in plants. New Phytol. 181, 759-796. doi: 10.1111/j.1469-8137.2008.02748.x 
Verret, F., Gravot, A., Auroy, P., Leonhardt, N., David, P., Nussaume, L., et al. (2004). Overexpression of AtHMA4 enhances root-to-shoot translocation of zinc and cadmium and plant metal tolerance. FEBS Lett. 576, 306-312. doi: 10.1016/j.febslet.2004.09.023

Vilaine, F., Palauqui, J. C., Amselem, J., Kusiak, C., Lemoine, R., and Dinant, S. (2003). Towards deciphering phloem: a transcriptome analysis of the phloem of Apium graveolens. Plant J. 36, 6781. doi: 10.1046/j.1365-313X.2003. 01855.x

von Wiren, N., Klair, S., Bansal, S., Briat, J. F., Khodr, H., Shioiri, T., et al. (1999). Nicotianamine chelates both FeIII and FeII. Implications for metal transport in plants. Plant Physiol. 119, 1107-1114. doi: 10.1104/pp.119.3.1107

Walker, D. J., and Bernal, M. P. (2004). The effects of copper and lead on growth and zinc accumulation of Thlaspi caerulescens J. and C. Presl: implications for phytoremediation of contaminated soils. Water Air Soil Pollut. 151, 361-372. doi: 10.1023/B:WATE.0000009901. 89000.40

Wang, J., Zhao, F. J., Meharg, A. A., Raab, A., Feldmann, J., and McGrath, S. P. (2002). Mechanisms of arsenic hyperaccumulation in Pteris vittata. Uptake kinetics, interactions with phosphate, and arsenic speciation. Plant Physiol. 130, 1552-1561. doi: 10.1104/pp.008185

Weber, M., Harada, E., Vess, C., von Roepenack-Lahaye, E., and Clemens, S. (2004). Comparative microarray analysis of Arabidopsis thaliana and Arabidopsis halleri roots identifies nicotianamine synthase, a ZIP transporter and other genes as potential metal hyperaccumulation factors. Plant J. 37, 269281. doi: 10.1046/j.1365-313X.2003. 01960.x

Wei, W., Chai, T., Zhang, Y., Han, L., $\mathrm{Xu}$, J., and Guan, Z. (2009). The Thlaspi caerulescens NRAMP homologue TcNRAMP3 is capable of divalent cation transport. Mol. Biotechnol. 41, 15-21. doi: 10.1007/s12033-0089088-X

White, P. J., Whiting, S. N., Baker A. J. M., and Broadley, M. R. (2002). Does zinc move apoplastically to the xylem in roots of Thlaspi caerulescens? New Phytol. 153, 201207. doi: 10.1046/j.0028-646X.2001. 00325.x

Whiting, S. N., Reeves, R. D., Richards D., Johnson, M. S., Cooke, J. A., Malaisse, F., et al. (2004). Research priorities for conservation of metallophyte biodiversity and their potential for restoration and site remediation. Restor. Ecol. 12 106-116. doi: 10.1111/j.1061-2971. 2004.00367.x
Willems, G., Frérot, H., Gennen, J., Salis P., Saumitou-Laprade, P., and Verbruggen, N. (2010). Quantitative trait loci analysis of mineral element concentrations in an Arabidopsis halleri $\mathrm{x}$ Arabidopsis lyrata petraea F2 progeny grown on cadmium-contaminated soil. New Phytol. 187, 368-379. doi: 10.1111/j.1469-8137.2010.03294.x

Wink, M. (1993). The plant vacuole: a multifunctional compartment. J. Exp. Bot. 44, 231-246.

Wünschmann, J., Krajewski, M., Letzel, T., Huber, E. M., Ehrmann, A., Grill, E., et al. (2010). Dissection of glutathione conjugate turnover in yeast. Phytochemistry 71, 54-61. doi: 10.1016/j.phytochem.2009.09.034

Xu, X., Shi, J., Chen, X., Chen, Y., and $\mathrm{Hu}, \mathrm{T}$. (2009). Chemical forms of manganese in the leaves of manganese hyperaccumulator Phytolacca acinosa Roxb. (Phytolaccaceae). Plant Soil 318, 197-204. doi: 10.1007/s11104-0089829-4

Yang, X. E., Long, X. X., Ye, H. B., He, Z. L., Calvert, D. V., and Stofella, P. J. (2004). Cadmium tolerance and hyperaccumulation in a new Zn-hyperaccumulating plant species (Sedum alfredii Hance). Plant Soil 259, 181-189. doi: 10.1023/ B:PLSO.0000020956.24027.f2

Zhao, F. J., Jiang, R. F., Dunham, S. J., and McGrath, S. P. (2006). Cadmium uptake, translocation, and tolerance in the hyperaccumulator Arabidopsis halleri. New Phytol. 172, 646-654. doi: 10.1111/j.14698137.2006.01867.x

Conflict of Interest Statement: The authors declare that the research was conducted in the absence of any commercial or financial relationships that could be construed as a potential conflict of interest.

Received: 03 May 2013; accepted: 03 September 2013; published online: 20 September 2013.

Citation: Leitenmaier $B$ and Küpper $H$ (2013) Compartmentation and complexation of metals in hyperaccumulator plants. Front. Plant Sci. 4:374. doi: 10.3389/fpls.2013. 00374

This article was submitted to Plant Physiology, a section of the journal Frontiers in Plant Science.

Copyright (c) 2013 Leitenmaier and Küpper. This is an open-access article distributed under the terms of the Creative Commons Attribution License (CC BY). The use, distribution or reproduction in other forums is permitted, provided the original author(s) or licensor are credited and that the original publication in this journal is cited, in accordance with accepted academic practice. No use, distribution or reproduction is permitted which does not comply with these terms. 